\title{
PELCANTA
}

\section{PLANNING TEACHERS' PROFESSIONAL DEVELOPMENT IN THE LIGHT OF MASTER TEACHERS PROGRAMMES}

\author{
Judit Szivák, Nóra Rapos, Sándor Lénárd, Erika Kopp
}

\begin{abstract}
The role of the teaching profession has significantly increased in international and Hungarian perspectives: as one of the most significant factors in the effectiveness of the public education system, it has become a central element of educational policy. The profession, is in the focus of the Public Education Strategy - a career model for teachers has been developed. The fourth level of this model is the master teacher level. Our study presents the results of the analysis of master programs $(n=813)$ prepared by candidates for this level. The results are presented along the dimensions of continuous professional development, innovation, inquiry, and knowledge sharing. The study is guided by the following research question: what outcomes did the master teachers planned in their programmes?
\end{abstract}

Keywords: teaching profession, career model, master teacher

\section{Introduction}

With the identification of the teacher as the most important factor for the effectiveness of public education, teacher policy has become a central element of EU sectoral policy, in particular the development of the teacher as a human resource, the focus on continuous professional development, career development, lifelong learning and the professional community context of this learning.

The EU's Education and Training $2020^{1}$ programme sets as a priority to support the development of national education and training systems, to develop complementary EU-level tools, and to promote peer learning and the exchange of good practice. In line with this, the principles of the Hungarian Public Education Strategy set out a number of objectives, in which the development of a career model for teachers is a key element.

Under the professional leadership of Eötvös Loránd University (ELTE), the missing master's and research teacher degrees were developed in the framework of the project TÁMOP-3.1.5/12-2012-0001, Completing, testing and correcting the teacher evaluation system.

In setting the stages of the career model, the developers considered the perspectives of teachers, institutions and public education development as factors determining the context for development, based on national and international experience, with a particular focus on the fact that the introduction of the stages should contribute to improving the effectiveness of the public education system, and thus address gaps, solve problems and promote improvements in public education.

\footnotetext{
${ }^{1}$ Council conclusions of 12 May 2009 on a strategic framework for European cooperation in education and training ('ET 2020') (2009/C 119/02)
} 
The master and researcher teacher qualification requirements focus on continuous professional development and embeds it in an organisational context, moving away from the individual perspective. The question arises as to how the new approach to professional development and learning can be integrated into professional activities in the pre-master teacher career stage, after the understanding of knowledge in terms of indicators in the assessment process, which is typically based on further training. Therefore, the focus of our investigation is the construction of this new expectation by teachers: how do master teachers interpret, plan and give content to their own professional development/learning in the interest of the development of the public education system?

In our study, we present our findings along the following research questions:

- What are the reasons that motivate master teachers to learn? How do they relate to previous events?

- What objectives do master teachers set for their learning activities in their master programs?

- are the reasons that lead them to set learning activities for their master's programme?

- What are the specific characteristics of master teachers' learning?

- What learning outcomes do master teachers envisage?

\section{Theoretical introduction}

For decades, professional and academic debates have centred on the question of the teaching profession (Hargreaves, 2010), both because of the multiplicity of approaches to the diverse theoretical frameworks (Sachs, 2016) and the different focuses of practical content that is of particular importance to the profession (Kennedy, 2005). As a sign of the consolidation of the paradigm, the literature now speaks of a mature profession (Sachs, 2016), a concept that clearly points to the consolidated status of the teacher as a professionalised occupation. This, however, does not mean that there is complete consensus on its content. The profession implies an ever-changing system, whose constituent elements interact dynamically to shape its content (Evetts, 2011), and so the study of its internal focuses and their shifts, without questioning the status of the teaching profession, has become a perennial issue in educational theory.

Although theories on the content of the teaching profession have different directions for the development of the profession, the theories have essentially the same goal (Sachs, 2016), which is primarily to raise the status of the profession and to have teachers who can support students' performance more effectively (Evetts, 2008). However, the path to these goals varies considerably. One possible dimension of these differences concerns the sources of development of the profession, essentially which actors catalyse change in the profession and in what direction. In this approach, we can speak of from within or from above professionalisation (Evetts, 2011).

Autonomy is at the heart of the theory focusing on from within changes regarding the content of the profession, as it is primarily the autonomous teacher who is able to develop the content of the teaching profession by applying his or her individual professional capital in an innovative and adaptive way (Sachs, 2016). The professional acceptance of the autonomous teacher has been a key moment in the process of professionalisation, as this approach recognises the legitimacy of the teacher's individual decision-making capacity and the importance of a supportive environment that can help the teacher to renew the content of the profession (Sachs, 2006). Some literatures refer to this approach as professions (Hargreaves and Goodson, 2006; Evetts, 2011).

Today, however, from the above professionalisation, or in other terms, organizational professionalism (Evetts, 2011; Gorman and Sandefour, 2011; Sachs, 2016; Torres and Weiner, 2018) has a similarly significant impact on the content of the profession. In this approach, the effort to improve and renew the content of the profession does not start from the teacher, but from one of the larger systems that provide the context for the teacher's activities. Learning is thus triggered by an external system of expectations that motivates, supports and controls at the same time. Some interpretations even attribute a stronger legitimacy to organisational professionalism, as it is not primarily based on the insights of individual members of communities of practice, but is defined by higher professional authorities (educators, academic communities, researchers, policy-makers) with a broader perspective and systemic thinking, 
thus creating a clear set of expectations against which teachers' work can be held accountable (Gorman and Sandefour, 2011; Evetts, 2011; Torres and Weiner, 2018).

Since the early 2000s, the countries of the European Union have been facing development challenges that are based on the context of adaptation and renewal in a changing economic, social and political environment. Against this background, challenges such as accountability and autonomy, centralised and liberal education policies and the innovation capacity of education systems, especially with regard to the renewed expectations related to teacher quality can be identified. Along these challenges, the specific aspirations of national education policies illustrate the search for solutions to global problems in specific contexts. Teacher policy has become a central element of EU sectoral policy, with a particular focus on the development of teachers as human resources, continuous professional development, professional career, lifelong learning and the professional community context of this learning.

The development of learning in professional communities of practice and learning organisations has become a policy priority in many public education systems and has been closely linked to the redefinition of the teaching profession and the development of support systems (e.g. Jackson and Temperley, 2007; Istance and Kobayashi, 2012). The systemic understanding of the importance of knowledge acquisition and knowledge sharing has also emerged in EU-funded programmes in Hungary and has become a dominant element in the 2007-2013 TÁMOP programs promoting learning organisation functioning, knowledge sharing and horizontal learning within and between schools, and the sharing of best pedagogical methods and good practices (Fazekas and Halász, 2015).

In order for a school to transform from a place of learning into a learning organisation (Senge, 1990) that is itself capable of change (and even of becoming a proactive leader of change), it is not only necessary to promote the individual learning of the members within the organisation, but also to facilitate organisational learning. Organisational learning, which in schools culminates through and beyond the learning of individual teachers, and which, independent of individuals, becomes an asset of the institution, is both a process and an outcome, that the leadership can influence through the organisational structure (Child, 2015).

The organisational level is not only a bridge between professionalisation at the level of public education and that of the individual, but also a key point. Collegiality within the organisation is the embodiment of the capacity for support and control that we discussed earlier in relation to professional occupation and organisational professionalism. It is at the level of the organisation that the process of professionalisation linking the individual to public education takes place.

While the content and path of individual professional development is always contextually (policy environment, organisation) determined and/or interacting with these environmental elements, the understanding of individual responsibility is also gaining increasing importance (Sachs, 2007, 2016). Today's understanding of the teaching profession is based on the approach that the individual is not only a passive victim but also an active agent of the systemic factors that influence him or her (cf. Hargreaves and Fullan, 2012; Sachs, 2007, 2016), i.e. the relationship is reciprocal and dynamic.

In order to set explicit national expectations for the professional knowledge of teachers, to improve the quality of education, to align and compare qualifications and to support and promote individual access to learning and progression, there is a growing demand for qualifications frameworks, standards and competency expectations (Coles and Werquin, 2009) worldwide. Among the several important issues currently preoccupying researchers looking at expectation frameworks from the perspective of the individual, the most prominent is understanding how the existence of these frameworks impacts teachers' individual learning processes. Although the question cannot be explored without a structural and content knowledge of the given framework or standard, the key question is how the content elements are related to and how distant they are from the teaching tasks that the teacher perceives and considers important, i.e. are they valid and authentic for the individual? In this respect, the role played by teachers in the process of developing the expectations is decisive, as is the role in which the expectations are formulated. That is, from the teacher's perspective, is it merely the monitoring function that comes to surface, or is the place, role and support for his or her individual learning visible, too (Ingvarson, 2002, 2003, 2007; Darling-Hammond et al., 2012). 
Internationally, there is a growing ambition to reinforce the complexity of the content of professional knowledge in frameworks, standards and assessment processes, to support learning embedded in the teacher's direct work, to promote the role and consciousness of individual learning embedded in the professional community, and to operate dynamic assessment systems that are able to recognise the existence of individual learning pathways as well. This reinforces the role of individual responsibility and the conscious planning and practice of teachers' learning (Guerriero and Deligiannidi, 2017).

\section{Master teacher degree}

In order to support the above, the development of a complex system of continuous professional development was identified as a key objective in the development of the Master Teacher's degree (level 4) in the Hungarian teacher career model, and as a result the pillars of the expectation system were to increase the innovation potential of the system, the research-based approach and to strengthen knowledge sharing.

Based on this, the new stage was defined, that represents a completely different approach and structure in the teacher evaluation system and a different way of thinking about the systemic function of evaluation: 'A master teacher is first and foremost an excellent teacher who, through his/her professional activity and high quality educational work, serves as a model for his/her colleagues (Education Office, 2016. 15.). The professional activity of a master teacher contributes significantly to the effectiveness of education. The professional activities of a master teacher can be defined along four dimensions: innovation activities for the effectiveness of teaching and learning, knowledge sharing activities, research activities and activities for continuous professional development. Above all, what sets master teachers apart from the teaching profession as a whole is their distinctive role in creating, sharing and applying the knowledge needed for effective professional work.

During the TÁMOP project, the teachers participating in the pilot programme received support in interpreting the definition of the master teacher degree, in preparing the documents necessary for the evaluation and they prepared their five-year master programme, that aims to make the teachers aware of and record their short and long-term goals; the pathway and activities leading to these goals; the resources needed for their realisation; the indicators of effectiveness, i.e. when the goals can be considered to have been achieved; and the type of support needed.

In a certain sense, these master programmes are historical documents of the development of public education in Hungary, in the sense that they represent how the most outstanding teachers think about the opportunities of their own activity, their commitments, and, in this context, about the perspectives of the renewal of the Hungarian public education system.

\section{The research}

The pilot project targeted nearly 5,000 teachers who were potential candidates for master and research teacher degrees. From these, nearly 1200 teachers were selected to develop their research and master programmes for the next five years in 2015. In our research, we analysed these programmes, highlighting the master programmes $(\mathrm{n}=838)$.

Taking the above into account, our research sought answers to the following question: what outcome (product, impact, etc.) did master teachers plan to achieve by the end of their five-year master's programme?

The coding of the general and detailed plan of the master programme was based on preliminary research findings, literature, guidelines for the qualification process for the Master Teacher degree and exploratory analysis of the texts. The categorisation of the objectives, activities and outcomes of the master programmes was determined on the basis of previous research findings. On the one hand, we used the OECD TALIS studies' clustering system for training needs (OECD, 2016), and on the other hand, we applied the categories used by the previous Hungarian national survey of teachers (Sági, 2015). In addition to the general and detailed master programme, we also processed the teacher's CV: formal 
qualifications, language skills, workplace (institution), job description, position and type and number of publications were recorded. This was also linked to data from his/her master programme, which were used as background variables for our analysis. The background variables were further supplemented by the profile of the master teacher (trainer, mentor, innovator or leader).

After coding and data cleaning, the data were subjected to various quantitative analyses. The analyses were mainly performed using descriptive statistics and cross-tabulations, and correlation and difference tests were carried out using Chi-square and ANOVA tests. For statistical tests, the significance level was set at $5 \%(\alpha=0.05)$.

\section{Theoretical frameworks for research on teachers' professional development}

\section{The result of continuous professional development}

The key to the articulation of professional development in the school context is linked to the question of effectiveness, which is essentially influenced by systemic responses. However, the effectiveness of continuous professional development (CPD) should be considered from two different perspectives.

The initial interpretations thus closely link continuous professional development to the issue of student achievement. The primary reason for this is that the turn of the millennium has highlighted changes in the world of education and the surrounding society, which have created new demands and new functions, and have thus made the professional expectations towards schools and teachers more complex (Recent Education Policy 2003; McKenzie et al. 2005; The Quality of Teacher 2006). These expectations, which have developed into teacher policy at the EU-level, have been underpinned by research that has provided credible evidence that teachers have a significant impact on student achievement (Hattie 2003; BarberMourshed 2007). The literature on the link between continuous professional development and student achievement has focused mainly on the structural features of teachers' learning (location, actors, subject matter, forms of work, etc.), their interpretation and the direct translation of what they learn into practice (Cole 2012; Pedder et al. 2010; Bell et al. 2010). In this interpretation, the primary goal of continuous professional development is to improve learner performance. However, the literature confirming the positive relationship also stresses that improvements in student achievement cannot be identified with test scores ${ }^{2}$ (Cordingley et al. 2005). Critical approaches explicitly emphasise that the teacher cannot be held solely responsible for student achievement and move towards qualitative, multi-perspective assessment $^{3}$ (Goe et al. 2008). Other studies also suggest that the identification of the relationship is more complex and can be studied by variables and partitioning (Baker 1999, cited in Villegas-Reimers 2003; OECD 2014).

Partly as a result of critical voices and research refuting effectiveness, another approach is gaining strength, focusing on the teacher himself (Korthagen 2017) and, as part of this, on the outcomes of the teacher's learning for his own professional development. These studies focus, for example, on issues of identity (Beijaard 2004), the personal reasons for the teacher's learning, motivation, the interpretation of pedagogical knowledge, and the affective elements of learning. Studies have shown a positive correlation between self-efficacy and participation in and effectiveness of training and learning (EdenKinnar 1991; Gist Schwoerer-Rosen 1989), and that these factors also have a positive impact on learning

\footnotetext{
${ }^{2}$ Effectiveness has meant, for example, increased motivation to learn and improved specific test scores (e.g. reading fluency, decoding efficiency, etc.), more effective learning management, more complexity in topic processing, etc.

${ }^{3}$ A teacher is considered effective if he or she 1) sets high expectations for all his or her students and helps students to meet those expectations; 2) contributes to the growth of students' academic knowledge, attitudinal and social development; 3) uses a variety of resources to plan and structure learning pathways, monitors students' progress, is adaptive as needed, and assesses learning by drawing on multiple resources; 4) contributes to the development of classroom processes and schools that provide for diversity and different ways of thinking; 5) collaborates with other teachers, stakeholders, parents, and educational professionals to ensure student success, especially for students with special needs.
} 
new methods (Allinder 1994; Bray-Clark-Bates 2003). These studies have also shown that the personal characteristics of the teacher play a much greater role in professional development and its effectiveness than previously thought (Korthagen 2017), leading to a critique of the role of systemic expectations and mechanisms.

\section{Planned development}

Strengthening the teacher's own role in continuous professional development reinforces the understanding of learning as personal, self-directed and based on autonomous decisions. Ppolicy expectations and research on the learning teacher emphasise that an essential element of professional development is the ability of the teacher to consciously plan, manage and analyse his/her own learning. This process is also reinforced by trainings and the competency frameworks that support subsequent professional development, and by the professional expectations set out in the learning outcomes ${ }^{4}$ (ColesWerquin 2009). Other approaches argue that it is not the further reinforcement of frameworks but the interpretation of a system of objectives that helps to systemise personal professional objectives (Nieuwenhuis and Van Woerkom 2007). Nieuwenhuis and Van Woerkom (2007), arguing against the separation of learning and work, point out that learning is not a prework activity but an integral part of it, and that when viewed in this way, a system of goals emerges that reinforces the role of personal goals, even in terms of performance (Table 1).

Table 1. System of goals inducing learning (based on Nieuwenhuis - Van Woerkom 2007: 69)

\begin{tabular}{|l|l|l|l|}
\hline Rationality & Description & Involved Institution & $\begin{array}{l}\text { Goal/Criterion for } \\
\text { Learning }\end{array}$ \\
\hline Preparation & $\begin{array}{l}\text { Learning as a preparation } \\
\text { for work }\end{array}$ & Education & Qualification \\
\hline Optimization & $\begin{array}{l}\text { Learning for effective task } \\
\text { execution }\end{array}$ & Work organisation & $\begin{array}{l}\text { Optimizing } \\
\text { productivity }\end{array}$ \\
\hline Transformation & $\begin{array}{l}\text { Learning for innovation } \\
\text { Eompetitiveness and } \\
\text { organisational vitality }\end{array}$ \\
\hline Personal development & $\begin{array}{l}\text { Learning for personal } \\
\text { goals }\end{array}$ & Individuals & Personal development \\
\hline
\end{tabular}

If we continue to see teachers' learning as preparation for future employment and preparation for new problems and challenges, we reinforce the formal nature of learning and exclude non-formal learning from teachers' learning, alongside personal goals.

This raises two further questions: 1) how informal, non-formal learning can be integrated into systematic approaches to professional learning (cf. measurement, effectiveness); 2) how teacher knowledge can be described (see Chapter 1), and how tacit knowledge elements beyond the visible, explicit knowledge content influence the teacher's everyday behaviour, actions, innovations and development (NonakaTakeuchi 1995; Guerriero-Deligiannidi 2017). Research shows that the majority of learning in the workplace is based on informal learning (Chivers 2011; Eraut 2011; Quintini 2018), so that both systems and institutions and schools need to pay more attention to understanding these processes. But it is equally important that educators themselves understand that interpreting, understanding and being aware of these learning processes is one possible way to do their work more effectively, and can create new frames for interpreting accountability. Acceptance of the role of tacit knowledge also means that new issues of designing and planning learning arise: individual and/or collaborative learning, reflection,

\footnotetext{
${ }^{4}$ An interesting dichotomy is that while this cognitivist approach to teacher behaviour, which emphasises self-regulation, is partly based on critical approaches to effectiveness, it is moving towards measurability through standardisation.
} 
knowledge sharing. "'It is increasingly clear that independent learning by isolated individuals is not sufficient for professional development that actually produces results, since, for example, the creation or transfer of tacit knowledge is most conducive to joint reflection and reflective collective action (Gilbert 2011; Bakkenes et al. 2009)' (Halász et al. 2015: 42).

Furthermore, the personal dimension of professional development, and in particular the affective and motivational aspects of learning, is also gaining in importance. Findings highlight that the main driver of teachers' learning is the desire to solve their own problems (De Ruyter-Kole 2010), the aspiration to achieve their dreams for novice teachers (Newman 2000), and a link between teachers' classroom activities and the satisfaction of their basic needs/desires (e.g., connectedness, competence, autonomy) (Evelein et al. 2008). Some models question the predictability of teachers' development embedded in systems and training, seeing it as a self-reflective process based on personal experience. In this interpretation, it is the tension coming from the incoherence between the personality layers that determine behaviour (emotions, beliefs, professional identity versus actions) that gives rise to the definition of development and learning goals (Korthagen 2017).

\section{Single career path, dynamic stages}

A basic principle in the literature on professional development is to see it as a process (Stéger 2010), with initial training, the induction phase and the rest of the career as separate elements. This approach is significant in that it draws attention to the lifelong learning paradigm and the specific learning characteristics of the major stages identified. This developmental path, which is often linear or step-bystep (cf. the career model), does not provide a nuanced interpretation of the theories of identity and the development of professional identity, which point to the specificities of its dynamic, multifaceted development (Akkerman 2011; Morisson 2013) and its contextual determination (Sachs 2005).

A further question is whether the several decades following the induction phase can be considered as a single unit, or whether it is worth thinking in terms of more nuanced units. The answer at the policy level is to expect a steady development of competences and to think in terms of phases. Research also identifies specificities that apply to more experienced teachers, highlighting that teaching experience (time spent in the classroom) is a critical factor in professional development and teacher transformation (Smith et al. 2003). The focus of learning for more experienced teachers is not on understanding theoretical dilemmas, but on supporting their students to achieve as well as possible (Guskey 1986). Examining the relationship between learning goals and professional concerns along the career path, Louws et al. (2018) show that in the early stages of the career, learning is more strongly driven by personal ambition and professional socialisation, while in the middle and late stages of the career, teachers are more motivated to continue their own work and have a stronger need to adapt to school goals and innovate.

However, it is precisely the above research on identity that draws attention to the fact that professional development is strongly linked to the development of personal identity, and that teachers' behaviour is strongly influenced by motivational and affective elements (Korthagen 2017), which are strongly linked to their personal destiny and beliefs (Hoekstra 2007; Kington-Gu 2007), as well as to the school environment, in addition to the cognitive elements of learning. All this suggests that the career stage that follows the induction, early career years cannot be considered as a coherent whole, but it would also be difficult to phase it inflexibly, as its focus is not on expectations but on personal learning. Thus, it is more useful to focus on identifying the supporting and inhibiting factors and to think in terms of a dynamic model of career development (Lunenberg et al. 2017). 
Interpreting the theory of continuous professional development used in the study and the expectations set out in the master programmes

"The master teacher consciously guides his or her professional development in order to maintain a high - master level - standard of his or her own work and to set an example in this field for his or her immediate and wider environment. In the case of the master teacher, professional development is selfdirected: the teacher is able to identify his/her shortcomings and areas for improvement, to set the direction of development for him/herself and to reflect on the development process. In the context of his/her chosen activities, the master teacher keeps himself/herself informed of the literature, is a member of communities of practice, takes part in further training and grant programmes, attends conferences, follows trends and new results in his/her field."

\section{Results}

The dimension of professional development was rarely found in the master programmes (8.8\%), but is closely linked to innovation (80.7\%) and knowledge sharing (70.2\%). While the Guidelines (Education Office 2016) and the four-dimensional activity model considered as a starting point in the Guidelines clearly articulated the need for planning professional development, many programmes only described the planned development, programme, and the professional development of the teacher (what is his/her personal, professional goal? what does he/she learn for this? what personal outcome does he/she expects?) was only captured at the level of activities, in a hint-like way. Thus, three categories were distinguished: 1) no reference to professional learning in the programme; 2) there is a plan for professional learning in the programme, but it is arbitrary; 3 ) there is a plan for professional learning in the programme and it is explicitly planned. This distinction will be used in the analysis only when justified and will be marked separately, otherwise categories 2 and 3 will be treated together and referred to as teachers who plan their learning (621 participants). Overall, planning for professional development appears in $76.2 \%$ (knowledge sharing $95.4 \%$, innovation $94.8 \%$, research $67.4 \%$ ), $60 \%$ of which is explicitly planned.

Of the optional profiles, mentors were the most likely to indicate a need for professional learning in their master programme, and leaders were the least likely to indicate a need for it (Figure 1).

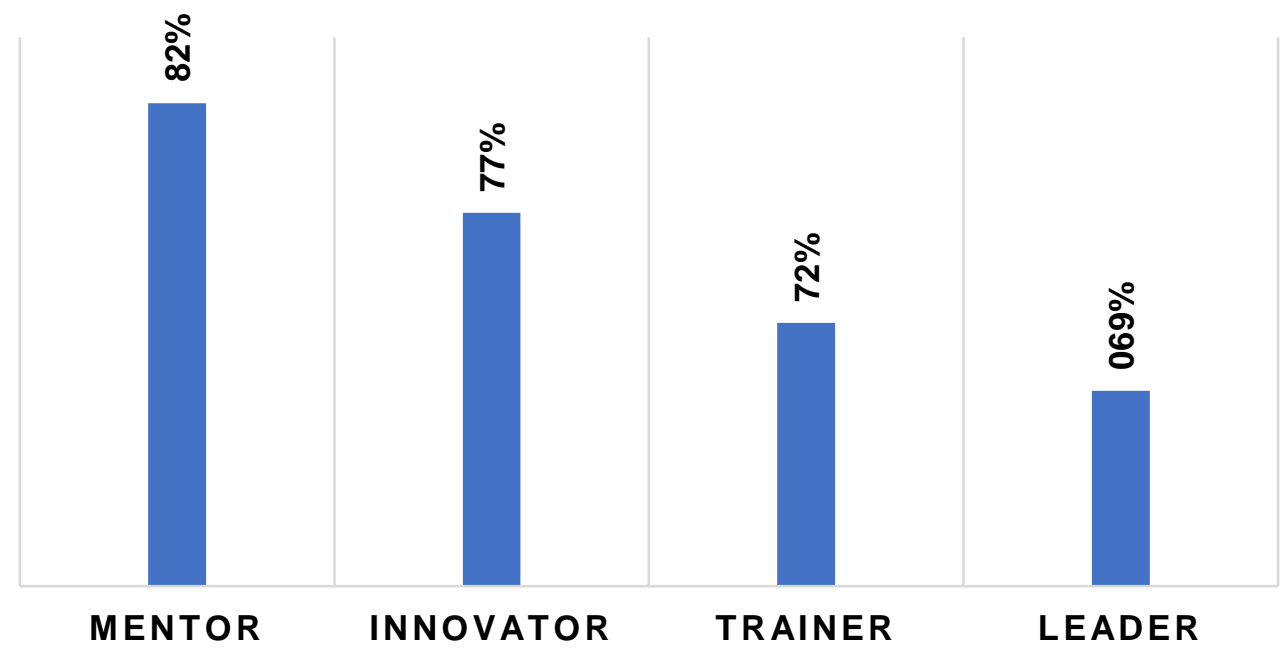

Figure 1. Those who planned their learning by profile, $\%(n=813)$ 


\section{Learning history and objectives}

The aspects examined to explore the reasons and purposes of learning in the master programmes are: a) the relationship between the planning of professional learning and the planning of previous events; $b$ ) the embeddedness of the reasons for learning; c) the relationship between the motives interpreted in the situation analysis and learning; d) the relationship between the purposes of the plans and the planning of learning.

The planning and embeddedness of the reasons for learning were linked to the study of previous events, because this was the part in which the applicant could explain the reasons behind the selection of the master programme (Figure 2). There is a fundamental difference between teachers planning $(n=621)$ and teachers not planning $(n=192)$ their learning in terms of the former consciously building on their own professional history, and connect to previous activities in their personal, institutional or professional communities $(\mathrm{p}<0.01)$.

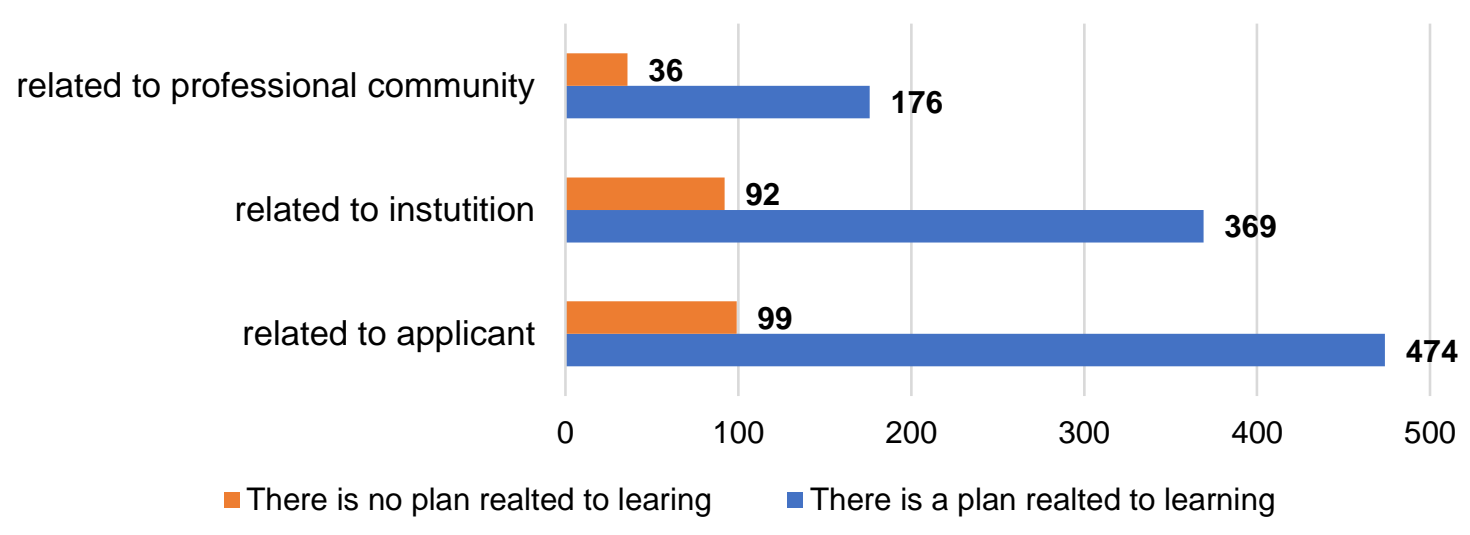

Figure 2. Embeddedness of previous events in activities related to the community, institution, applicant, people $(\mathrm{n}=813)$

Teachers who had planned their own learning in their professional development plan $(n=621)$ were most likely to link the analysis of the programme's history to their own personal pedagogical activities $(n=474,76 \%, p<0.01)$. The professional community as a basic unit for joint activities did not dominate either among those who planned their learning $(n=176,28 \%)$ or among those who did not $(n=36 ; 5 \%)$, but the institution was an important framework for planning conscious learning activities $(n=369,59 \%)$.

Among the teachers $(\mathrm{n}=581)$ who carried out a situation analysis in their master programme, learning is most strongly motivated by individual aspects: analysing their own perspective, looking for solutions to problems within it, interpreting previous learning experience. Institutional characteristics are also a strong motivator. Only after all this does the first, student-related element emerge, which is linked to the learner's academic performance and subject. In contrast, the impact of activities linked to the various forms of cooperation: international or other institutional experiences, professional conferences, etc., play almost no role in the situation analysis of the learning planners. And the elements related to evaluation are also ranked between 8 and 12 (Table 2). 
Table 2. Motives related to learning in the situation analysis of master programmes $(\mathrm{n}=581)$

\begin{tabular}{|c|c|c|c|c|}
\hline $\begin{array}{c}\text { Level of } \\
\text { significance }\end{array}$ & $\begin{array}{c}\text { Content elements of situation } \\
\text { analysis }\end{array}$ & $\begin{array}{c}\text { Learning plan } \\
\text { exist }\end{array}$ & $\begin{array}{c}\text { Learning plan is } \\
\text { non-existent }\end{array}$ & Ranking \\
\hline$(p<0,01)$ & teacher's own perspective & $384(81,7 \%)$ & $86(18,3 \%)$ & 1. \\
\hline & institutional characteristics & $339(78,7 \%)$ & $92(21,3 \%)$ & 2. \\
\hline$(p<0,01)$ & $\begin{array}{c}\text { teacher's individual learning } \\
\text { experiences }\end{array}$ & $255(87,6 \%)$ & $36(12,4 \%)$ & 3. \\
\hline & students' learning outcomes & $226(78,2 \%)$ & $63(21,8 \%)$ & 4. \\
\hline$(p<0,05)$. & change in students' characteristics & $117(77,0 \%)$ & $35(23,0 \%)$ & 5. \\
\hline$(p<0,01)$ & students' behaviour & $125(83,3 \%)$ & $25(16,7 \%)$ & 6. \\
\hline & research, literature & $116(84,7 \%)$ & $21(15,3 \%)$ & 7. \\
\hline & self-evaluation and assessment & $94(76,4 \%)$ & $29(23,6 \%)$ & 8. \\
\hline & cooperation with other institutions & $96(83,5 \%)$ & $19(16,5 \%)$ & 9. \\
\hline & external evaluation, assessment & $80(80,8 \%)$ & $19(19,2 \%)$ & 10. \\
\hline & creation of new educational profile & $66(78,6 \%)$ & $18(21,4 \%)$ & 11. \\
\hline & student feedback & $46(78,0 \%)$ & $13(22,0 \%)$ & 12. \\
\hline & conference participation & $48(81,4 \%)$ & $11(18,6 \%)$ & 13. \\
\hline & other institutional experience & $32(84,2 \%)$ & $6(15,8 \%)$ & 14. \\
\hline & international cooperation & $28(82,4 \%)$ & $6(17,6 \%)$ & 15. \\
\hline
\end{tabular}

Teachers who had developed a learning plan in their master teacher programme $(n=621)$ were more likely to have formulated their plan based on their individual perspective and previous learning experiences. There is also a significant relationship between the representation of learners' behaviours and research and literature analysis in the learning plan.

\section{Goals}

Among the teachers who planned their professional learning the most, the development of their own good practice or the adaptation of good practice seen from others appeared as the goal, and in this case the relationship was also significant $(p<0.05)$. A large number of teachers who planned their professional learning also chose to develop new curricula, teaching-learning programmes, programme packages and textbooks. However, collaboration and communication did not appear in half of the plans (Figure 3).

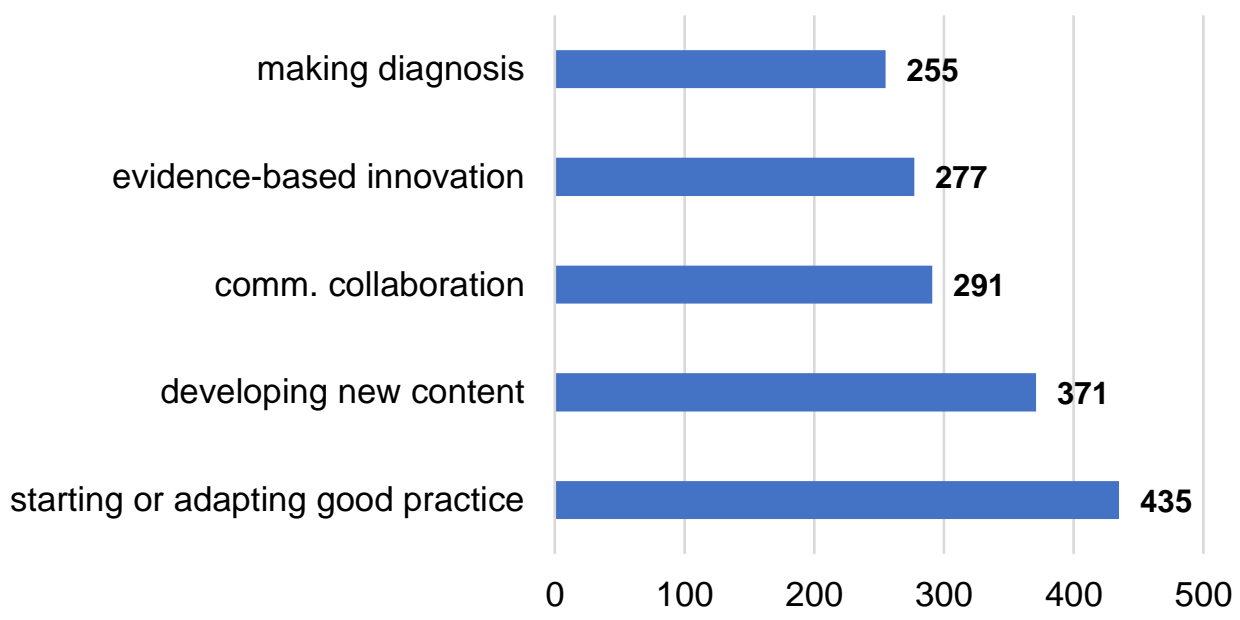

Figure 3. Master programme objectives of those planning to undertake professional learning

$$
(\mathrm{n}=621, \text { multiple answers possible) }
$$


When we split those who plan their professional learning (have a professional learning plan in the programme but not consciously planned; have a professional learning plan in the programme and explicitly planned), we see a significant difference in the good practice and evidence-based innovations: in both cases, those who explicitly planned their learning are those who set these goals more often ( $\mathrm{p}<$ $0.05)$.

While professional development and teacher learning cannot be seen merely as a consciously driven cognitive activity, they are also seen as a first step in promoting personal professional engagement, responsibility and self-efficacy (Czerniawski 2013; Janssen et al. 2012; Gravani 2007). In this sense, learning objectives represent the desired change in teachers' behaviour, and cognition can be seen as a linking of theory and practice (Zwart et al. 2008). An important finding is therefore that master programmes typically include the planning of learning. Teachers' thinking about their own learning is, however, predominantly self-centered. The antecedents and motives that induce learning are linked to personal professional activity. The reflections of the situation analyses are also primarily interpreted in terms of their own activities, while learning and knowledge acquired through cooperation with others is not a prominent element. External knowledge is derived from literature and research findings, and while the dimension of continuous professional development is closely linked to knowledge sharing, this is not emphasised in the first phase of learning design. This reinforces the idea that the spring of professional development lies in understanding the teacher's personality and motives (Eden-Kinnar 1991; Gist-Schwoerer-Rosen 1989; Korthagen 2017). At the same time, the oversight of collaboration makes it difficult to make tacit knowledge explicit, to learn in a professional community, to solve problems and to learn new perspectives.

Among more experienced teachers, the emergence of organisational embeddedness is generally perceived as more dominant, and personal motivation is associated with the search for challenges and innovation (Louws et al. 2018). Master teachers' aspirations related to continuous professional development did not confirm a stronger organisational embeddedness, while the intention to develop and test good practices and the linking of professional development to innovation highlight teachers' personal will to do something and take responsibility.

\section{The learning process}

The learning process is discussed in three aspects. First, we touch on the relationship between the situation analysis of the master programme and the planned learning activities, to see the internal coherence of the plans. The content of the planned learning will be analysed and, finally, the forms of learning will be examined in conjunction with the involvement of the planned actors.

\section{The relationship between situation analysis and learning activities}

Only in a few cases was there a correlation between the typical focus of the situation analysis and the planned learning activities. 5 . In those plans where the situation analysis was based on the previous individual learning experience, plans for further reading and exploration of literature, self-reflection, linking to professional groups within and outside the institution, attending conferences were more important, while the idea of further learning was least likely to be based on personal professional discussions ( $\mathrm{p}<0.01)$. In those plans where the individual's perspective (ambition, lack of knowledge) was the dominant factor in the situation analysis, teachers built their planned learning more strongly on self-reflection ( $\mathrm{p}<0.01)$, but were far from calling in the support of a mentor $(\mathrm{p}<0.05)$. Those analysing the characteristics of the institution were less likely to attach importance to reading professional literature, attending classes within and outside the institution, and organising in-service training in their learning plans, in contrast to being involved in professional groups within the institution $(\mathrm{p}<0.02)$. Teachers' learning plans analysing student performance were characterized by active intra-institutional

\footnotetext{
${ }^{5}$ The first four ranked factors in the situation analysis were examined in relation to the planned learning activities.
} 
professional community learning and self-reflection ( $\mathrm{p}<0.01)$. Overall, situation analyses based on individual learning experiences showed the highest correlation with the planning of learning activities. The individual perspective and learning experience strengthened the role of self-reflection, the institutional perspective pushed the plans towards running internal professional groups, and these activities were integrated in the student perspective.

\section{Content of the learning activity}

Two approaches to the content of the activities were examined among teachers planning their learning $(\mathrm{n}=621)$. In the first approach, we built on the range of activities developed on the basis of in-service training contents identified in the OFI research in 2014 (Sági 2015; Scheerens et al. 2003; 2007).

Among the master teachers who planned their learning, the most common content of planned learning activities is the development of teachers' foreign language skills (69\%), but there is also a high proportion of activities aimed at developing digital skills (55.7\%). In addition to subject knowledge (61\%), plans to develop methodological and pedagogical knowledge (55.6\%) are also dominant. These four lists are the most important in determining the content of learning, but they only indirectly support students' learning. Complex personal development (career guidance, talent support), extra-curricular activities and support for individual learning account for a smaller share of teachers' plans (Figure 4).

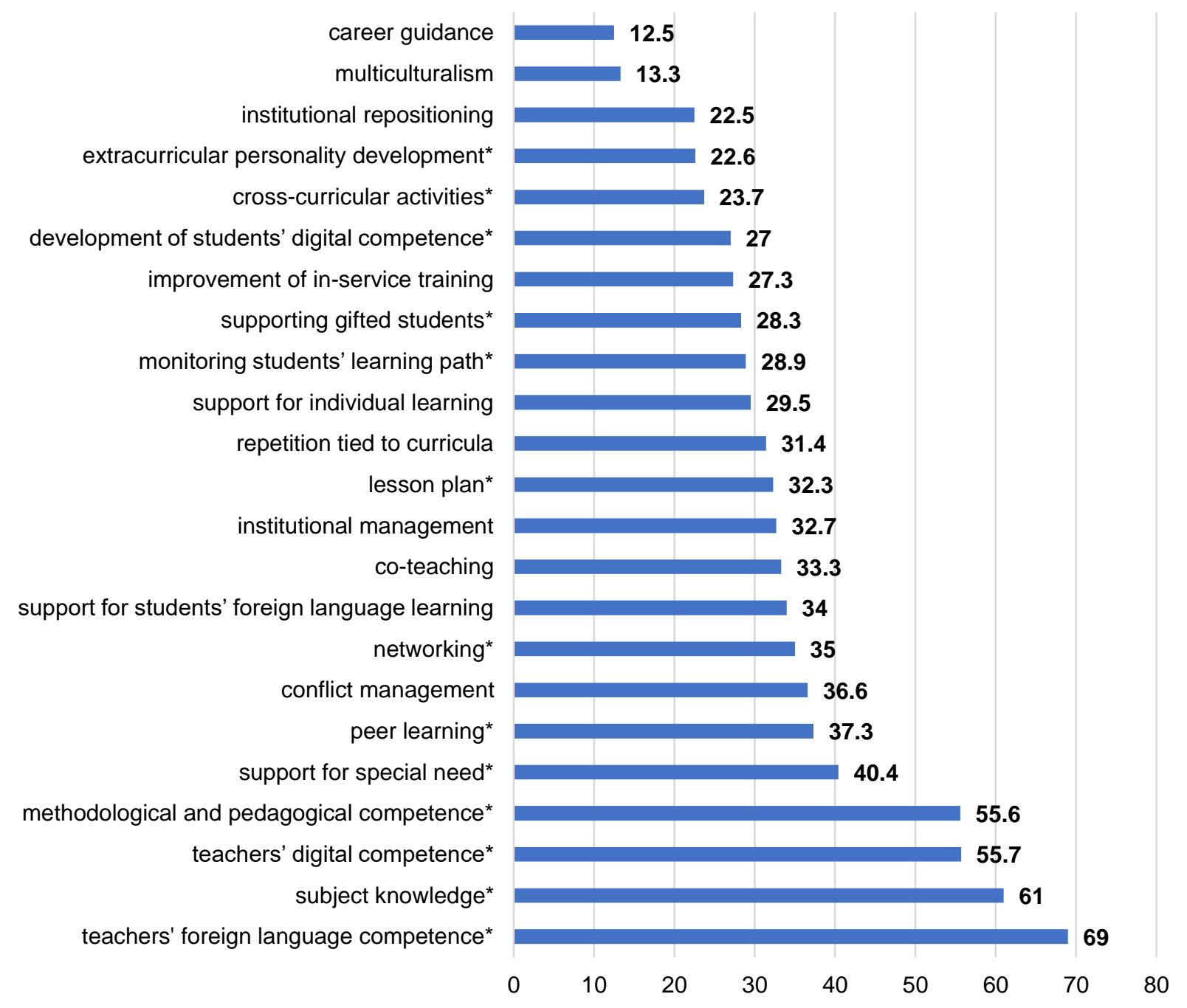

Figure 4. Content of planned learning activities among teachers planning their learning according to the OFI (Sági 2015), \% $(n=621 *=p<0.01)$ 
The content of the plans is mainly focused on the development of teachers' individual knowledge development, while peer learning and networking characterised only one third of the programmes. Compared to the 2014 in-service training data (Sági 2015), only 4\% of master teachers' plans included foreign languages and $12 \%$ included digital content, while their needs go far beyond this, according to the present research.

Looking at content focus from the other approach, subject content-related plans (expectation of higher student achievement, content quality) (Scheerens et al. 2003; 2007) are also primary, indicating a classical understanding of the role of teachers by master teachers, i.e. they want to develop in an area that reinforces the perceived or real quality of their teaching (Figure 5).

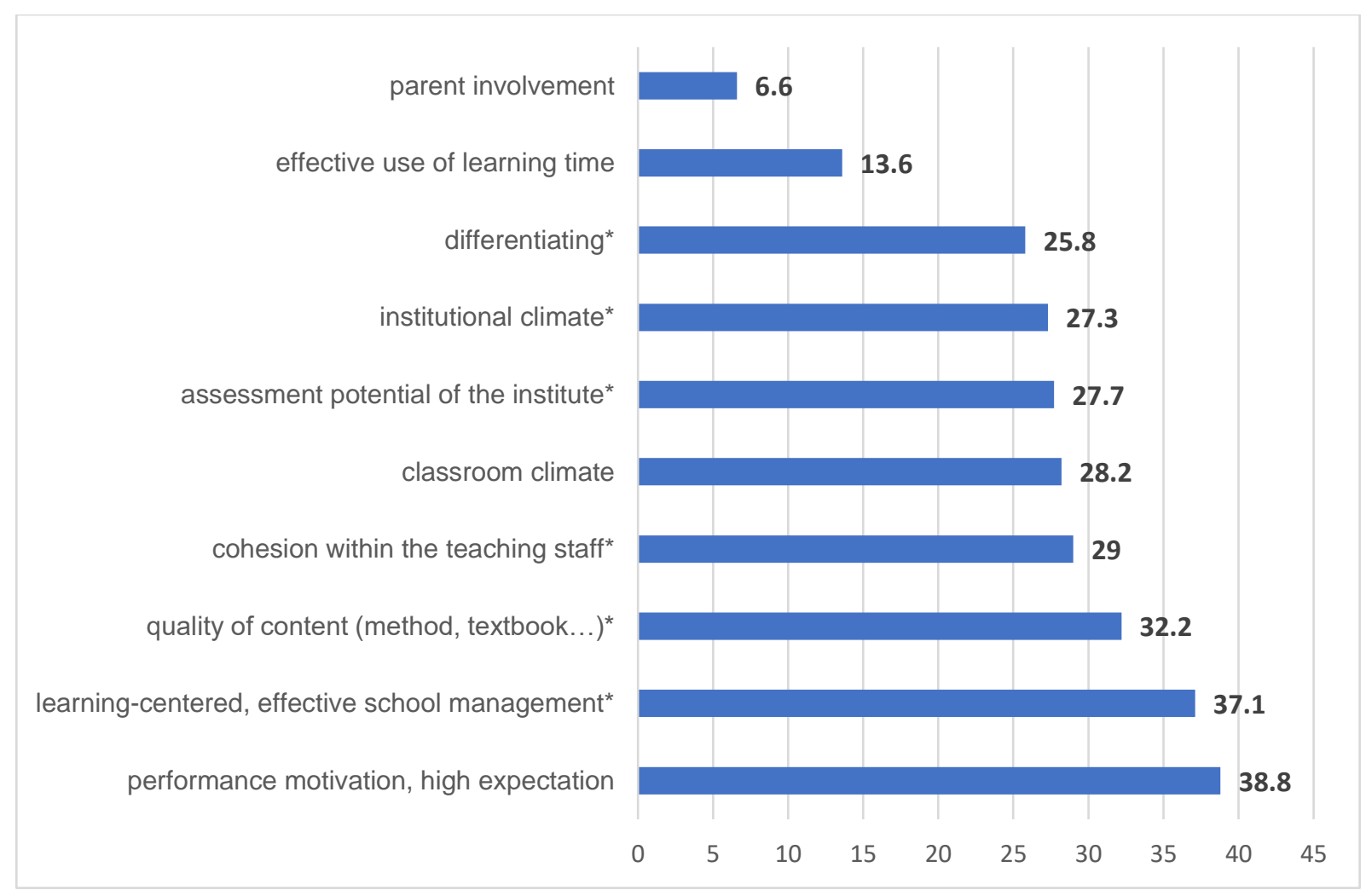

Figure 5. Content of planned learning activity among teachers planning their learning, $\%$

$$
(\mathrm{n}=621 * \mathrm{p}<0.01)
$$

At the same time, the emphasis on institutional leadership and the cohesion of the teaching staff points to the emergence of a new understanding of the role of teachers in the organisational functioning of the institution.

\section{Typical forms of learning activities and planned collaborations}

Among teachers $(n=621)$ who plan their learning, planned learning activities bring a clear change in the role of collaboration. Among the learning activities, the proportion of planned participation in professional groups and workshops within the institution is close to $65 \%$, but half of the programmes include participation in conferences and professional discussions. The role of self-reflection remains dominant (49.4\%). However, the use of a mentor does not become desirable (9\%) and the planning of classroom visits is also less important (7.7\% outside the institution and $17.6 \%$ inside) (Figure 6). 


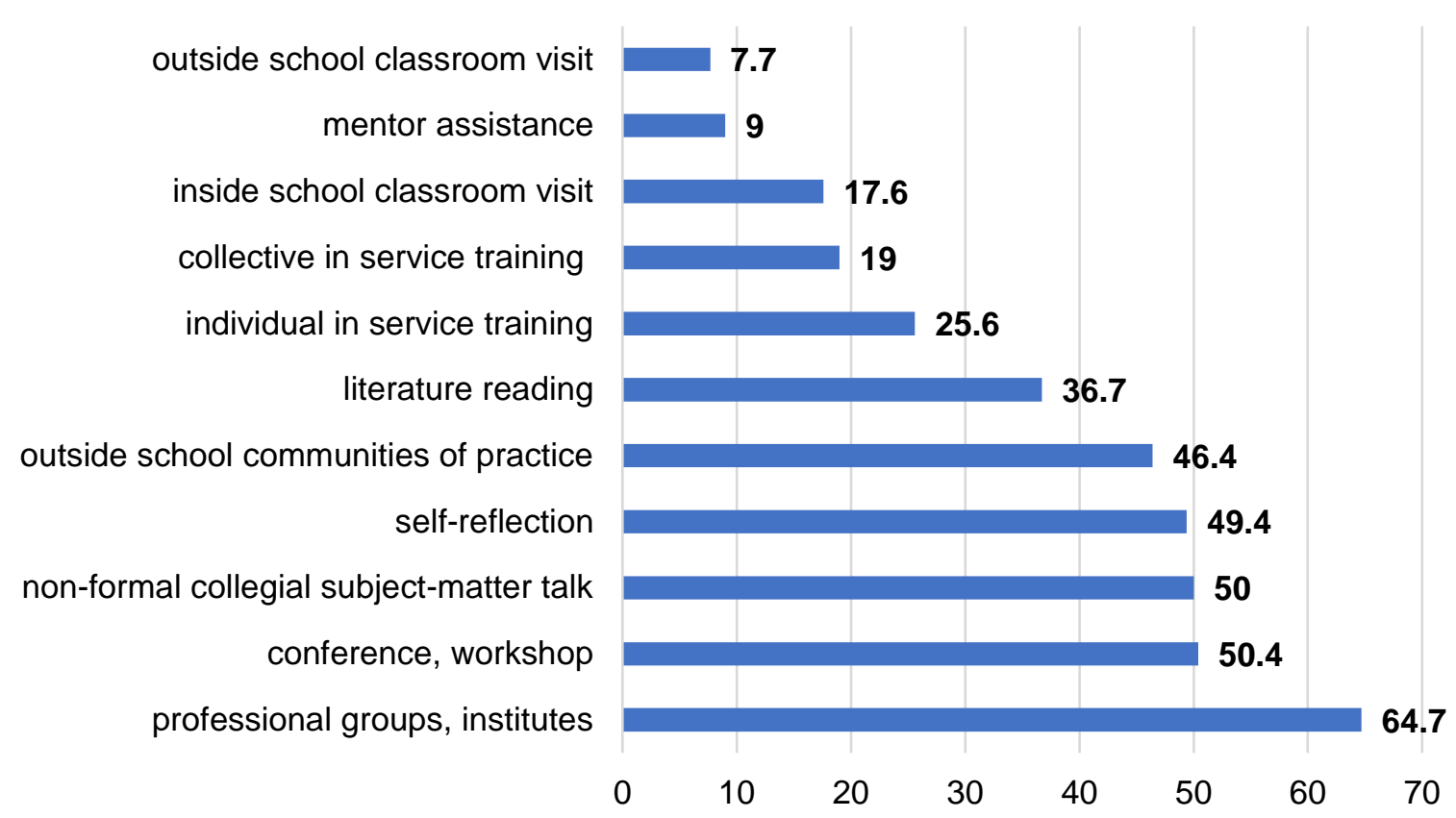

Figure 6. Master teachers planning their learning activities, \% (more than one item could be coded)

The planned forms of learning were combined into aggregate variables and their relationship with the planned actors involved in the learning was examined. In the aggregated variables, we distinguished between those planning collaboration within the institution (non-formal discussion with colleagues, participation in professional groups, classroom visits), those planning collaboration outside the institution (professional communities outside the institution, classroom visits, conferences and workshops), those planning traditional formal activities (reading literature, in-service training, participation in individual training), and those planning self-reflection (self-reflection, mentor assistance). Chapter 7 on the overall programmes states that "... in less than half of the masters programmes $(46 \%)$ we identified some kind of external collaborating partner or partners... it is clear that parents are the most frequent target group $(41 \%)$, with hardly any other group or organisation other than higher education institutions (23\%) and professional organisations (18\%). In other words, the master programmes tend to remain within the school world, attracting few partners, and parents are the most prominent among them." Master teachers in the sub-sample planning their professional development plan their professional contacts differently, planning essentially outward learning, and learning from external actors becomes dominant (62.8\%), but contact with parents in professional development activities almost disappears (3.2\%). Those who plan their professional learning are most open towards higher education institutions in their master plans, and the extent of any planned contact beyond the subject and school level is very low (Figure 7). Among the reasons, it can be assumed that those planning their professional learning see learning itself as a process that is most closely linked to formal learning or direct teaching practice, and thus cooperation is also directed towards these partners. 


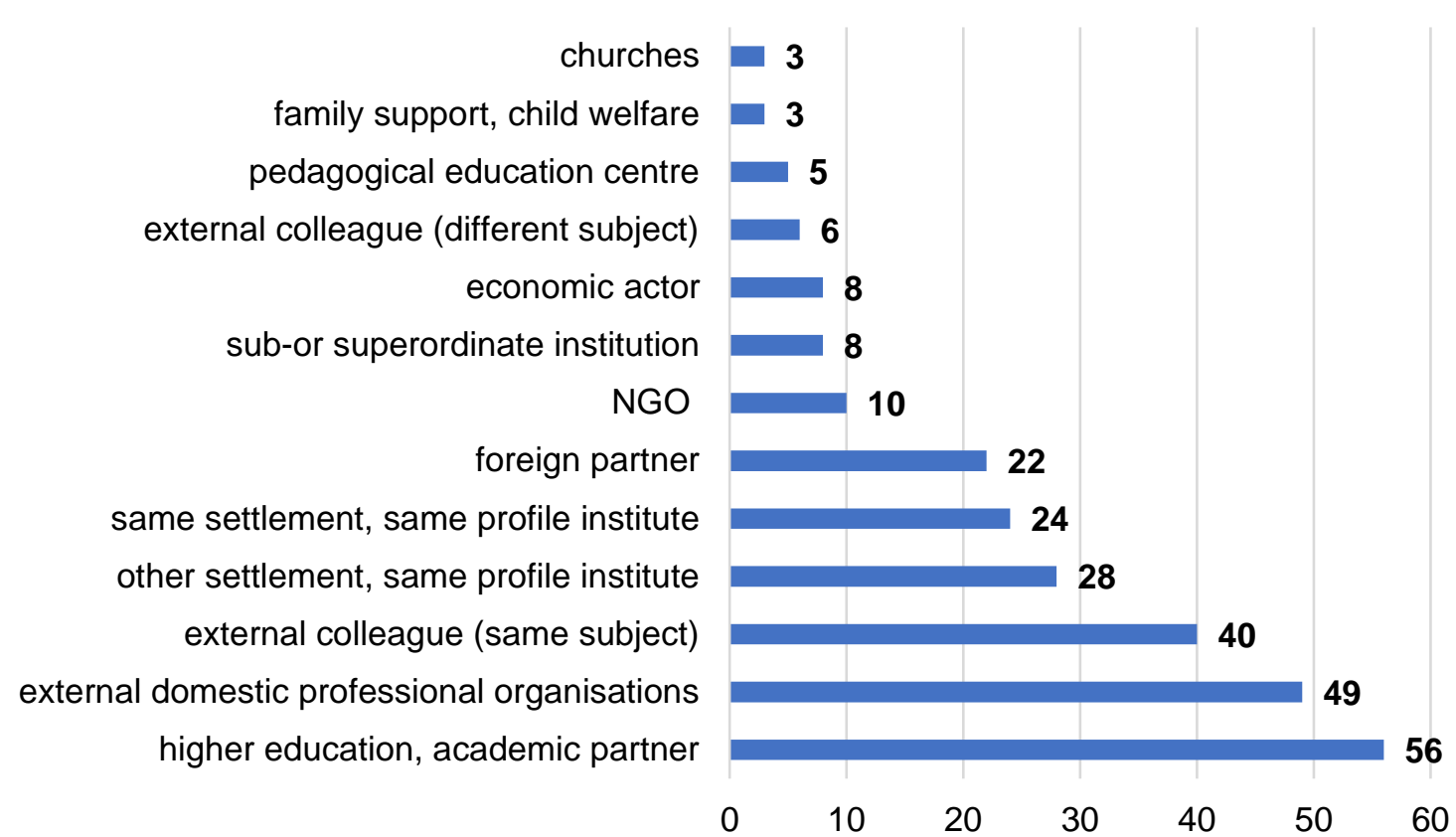

Figure 7. Planned external contacts of those planning their professional training, $\%(n=621)$

It is characteristic of all groups described by the aggregate variable that they involve anyone in any activity not related to their own learning much more than in their own professional learning (Annex 3).

Planned learning of activities related to their own professional development within the institution will be from those closest to the teacher according to the plans (peer 21.4\%, institutional colleague $21.7 \%$ ). Master teachers planning their learning only turn to teachers of other subjects $(9.5 \%)$, or other age groups (3.5\%) or to institutional specialists (5.2\%), so there is little crossing of boundaries. The involvement of leaders in their own learning does not even reach 10\% (9.5\%), so these activities are unlikely to form an explicit basis for institutional learning, or becoming a learning organisation (Annex 3).

Self-analysts are those who most intensively envisage the involvement of any actor within the institution in their own professional development (Annex 3).

The external group is the most active in their plans to involve external actors (76.2\%) and the least likely to involve parents in their own professional development (2.6\%). The group planning in-house learning and the group planning traditional forms are the most similar; the difference is that those planning in-house learning want to involve their subject colleagues more intensively (Annex 3).

The aggregate variables of the planned forms of learning were not correlated with the background variables (length of time in career, number of qualifications, length of further training, job description, size of municipality, maintenance provider, job position, number of language exams). Overall, the study of the learning process further confirmed the evidence of loneliness and thinking in personal space for those planning to undertake professional learning. The relationship between the situation analysis and the planned learning activities revealed that planning from the students' perspective was the most likely to ensure that the master teachers interpreted institutional and personal professional goals and the support of their own professional goals and their achievement as a whole in their master teacher programme.

The directions that master teachers focus on in their planned learning (foreign language learning, preparing for digital challenges, developing higher subject expectations) serve to strengthen their own everyday teaching. Within the institution, the most important link is the subject partner in learning, but beyond the institution, the search for a subject partner is also crucial. All this suggests that the image of expert, subject-area teachers who want to become even better determines the master teachers' plans, and this also dominates their own learning plans (Sasch 2005). Collaboration and knowledge sharing, as defined in the Master Teacher Expectation System (Education Office 2016), in the dimension of continuous professional development, mainly implies leaving the institution, which is not conducive to 
strengthening organisational learning. The picture of the partners involved in collaboration shows that master teachers do not yet have a good sense of how their work can be strengthened by the perspective of another actor. The subject focus and the narrow range of partners involved among those planning their professional learning, when the master programmes are implemented, predict a moderate potential for innovation. The analysis of the learning process shows a positive change in the forms of learning. Under Hungarian legislation, continuous professional development is linked to formal continuing training. In contrast, those planning their learning envisage more varied forms of learning that go beyond formal learning. Compared to the Hungarian data, the role of direct forms of learning linked to classroom processes is strikingly reduced, and the emphasis shifts to professional discussions and the need to analyse one's own work. The latter is presumably a feature of the later stage of the career. This specificity suggests the importance of more flexible support for the long phase of continuous professional development, which can take up to 40 years, and which requires more effective educational policy responses and support. Overall, however, the question arises as to how new forms of learning without organisational support can ensure that master teachers make effective use of learning situations beyond formal training to enhance their knowledge.

\section{Planning knowledge-sharing activities related to professional development}

Interpreting knowledge-sharing activities

The effectiveness of educational change and its media can be defined as a complex and adaptive system, in which the most significant factor is teacher learning (McLaughlin, 1990). In addition to the commitment and willingness of participants to change, the success and sustainability of the introduction of change (educational improvement) depends on the ability of educators to identify the areas of intended change, developmental-learning goals and processes (Hall, 2013; George et al., 2013). Accordingly, the focus of the context for development interventions has been on the learning culture of organisations and individuals, the development of professional communities and learning networks that provide learning, the changes in shared learning processes, and the effectiveness of linking old and new knowledge (Cohen and Levinthal, 1990). A key question in the analyses of individual and organisational change researchers (Vera et al., 2011; Eisenhardt and Martin, 2000; Teece et al., 1997) is how actors are able to identify, understand and use new knowledge that is generated from within the organisation or from outside. This capability is most often defined in terms of knowledge management, which (although many interpretations are known) can be summarised in five states: 1) identifying potentially valuable external knowledge, 2) acquiring it, 3) assimilating it, 4) creating new knowledge, and 5) utilising it (Fazekas and Halász, 2018).

\section{Outcomes linked to the planned knowledge-sharing activity}

The results of the analysis of the Masters programmes show that the knowledge sharing, or more precisely the expectations related to knowledge transfer, closest to their core professional role, is the most effectively interpreted by teachers. Knowledge sharing is most significantly exploited within their own professional group (79.5\%), but master teachers also plan knowledge sharing activities for the whole organisation at a high rate $(64.1 \%)$, while exploitation in external professional contexts is significantly less common.

In master programmes, knowledge sharing is most often linked to innovation, so the transfer of innovation in their own practices is the most meaningful form of knowledge sharing. There is a clear link between knowledge sharing and planning for professional self-development, i.e. master teachers who consciously plan their professional development also think about sharing the results of their learning, i.e. the professional development of their colleagues.

The activities planned in the masters programmes, which are also linked to knowledge sharing, contribute primarily to more effective teaching of the subject. This is followed by knowledge-sharing activities linked to student learning support, where gifted education is far ahead of the development of students with learning or social disadvantages. Knowledge sharing is more about educational successes 
than problems. Knowledge-sharing activities do not differ significantly either by place of assignment or by job title, so that leaders are not characterised by stronger knowledge-sharing activities. The fact that leaders' planning does not show differences in this respect may be significant for the development (difficulties) of the learning organisation of professional communities.

The results of the master programmes, which are also related to knowledge sharing, have the greatest impact on the whole teaching community (49.9\%) and on the organisation (49.4\%). Although smaller, but still significant, proportions of master teachers planned to impact their own development and knowledge growth (32.0\%), a few individuals (23.9\%), and the relationship between their organisation and its environment $(23.2 \%)$ through their outcomes. The least planned impact of knowledge sharing is at the international level (3.2\%).

The knowledge-sharing products (Annex 2) formulated by teachers in their master programmes are firstly interpreted within the institution (e.g. professional workshop within the institution, good practices in education, tutorials/workshops) and secondly in knowledge-sharing beyond the institution (e.g. publication, conference presentation, networking, professional workshop, series of programmes beyond the institution, online community space, platform). In addition, there are also outputs related to teacher education and training, albeit to a lesser extent (e.g. teacher education/further training improvement activities, accredited teacher training course description, module description, teacher training course description). The results identified in the area of knowledge sharing reflect the expectations: the implementation of the master programme supports the development of the narrower and, to a lesser extent, the wider (local, national) professional communities, contributes to the institution's functioning as a learning organisation. In the design of the outcomes (compared to the design of the activities), the intention to create forms of knowledge sharing beyond the organisation is more strongly reflected. The potential for wider professional collaboration and knowledge exchange is evident in the implementation of the master programmes.

There is not always a significant correlation between knowledge-sharing outcomes and activities leading to outcomes, i.e. teachers did not always plan relevant outcomes when planning of activities. In the case of in-house workshops and tutorials as outcomes, the planning of activities related to them can be identified, while for workshops and online platforms beyond the institution, no correlation with planned activities can be identified

\section{Intended outcomes of learning}

Teachers $(n=621,63 \%)$ interpret the impact of planned learning outcomes as their own personal knowledge, but do not report any plans for an impact beyond this on students, groups of children, public education, the educational system or the region. Importantly, however, nearly a fifth of the plans already indicated the hope of an impact on the organisation (23\%) or the working community (21\%) among those who planned their professional development.

The coherence of the planning is shown by the way in which the planned activities and results are linked to each other. This is of particular importance for learning, as it can indicate how consciously one is interpreting one's own learning, how one sees its role, and the anticipated importance of its usefulness. The data for the full sample and those planning continuous professional development differ (Figure 8). Master teachers who plan to increase their own knowledge consider their own knowledge to be realised in outcomes related to subject methodology/pedagogy and subject matter, compared to the full sample, where it is mostly planned to be realised in collaboration with colleagues and lesson planning. Both the full sample and the sub-sample of planners of continuous professional development have a narrow range of intended outcomes, suggesting that the expected outcomes do not drive teachers' planning processes, but that the teachers primarily plan activities, the relationship of which to outcomes is not always well thought through. 


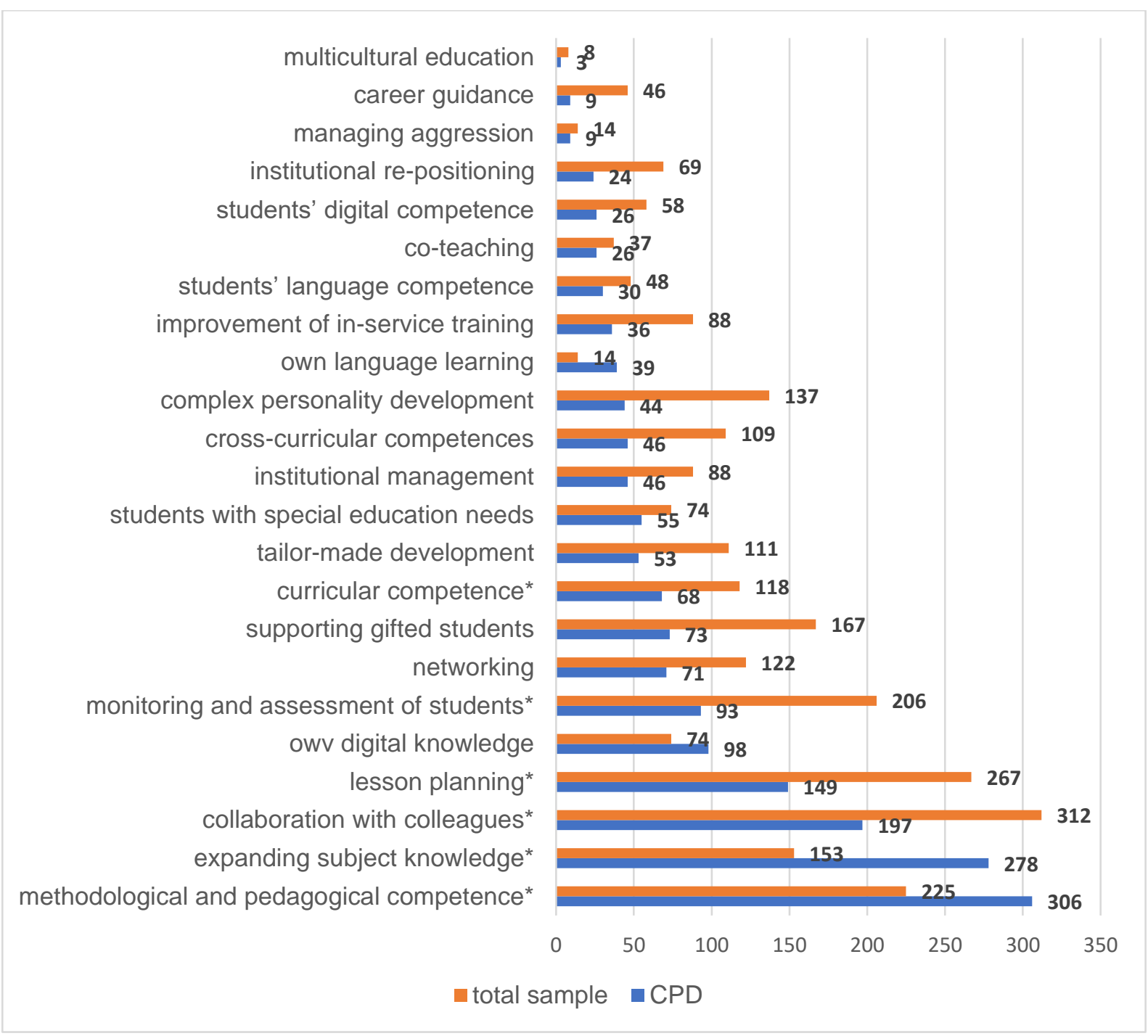

Figure 8. Relationship between planned activities and planned outcomes in the total sample and among those planning CPD, person $\left(\mathrm{n}_{\text {total_sample }}=813, \mathrm{n}_{\mathrm{CPD}}=621, *=\mathrm{p}<0.01\right.$ )

Only six planned activities and planned outcomes show coherence and correlation for both samples, showing a classical set of teacher activities: own subject and methodological knowledge, lesson planning, student assessment and curriculum knowledge. There is one important exception: collaboration with colleagues.

Professional knowledge as interpreted by master teachers does not show the diversity that international research suggests. As the function of the school changes, the content of teacher knowledge needs to broaden, and the demands of this (e.g. multiculturalism, career guidance, co-teaching, language skills of students, support for student learning in digital spaces, etc.) have become dominant in expectations of teacher knowledge (Recent Education Policy 2003; McKenzie 2005; The Quality of Teacher 2006). The evidence from the master plans is that teachers who plan their learning do not expect such outcomes from their learning, which of course does not mean that they do not have these elements of knowledge. This suggests that the role interpretation of the master teachers studied is subject teaching focused, less responsive to the societal expectations towards teachers.

\section{Summary}

The results suggest that the vast majority of master teachers tried to plan the path and content of their learning. However, this planning is individualised in its aims and outcomes, and is characterised by a narrow understanding of professional knowledge. It reveals new learning opportunities in its forms, but 
has little organisational embeddedness. Teachers are striving for perfection, there is no sense of a conscious commitment to learning by trial and error.

We can conclude that if the master teacher programme is implemented as planned, it will give many teachers a chance to improve their knowledge and to achieve or support other planned changes, but the majority will remain by simple, rigid, inward-looking practice, not personally interested or involved in improvement; some teachers recognise that they are agents in their own learning, continue to seek activities to contribute to it or find new ones, but their effectiveness is overshadowed by the lack of a supportive immediate environment. Professionalism remains a personal matter, and the environment for the teacher is the larger system of public education, not the immediate institution. This shift is too great to have a strategic impact.

Overall, we can say that the conditions for the success and sustainability of the introduction of knowledge-sharing expectations in teachers' master programmes are basically given. There is a strong commitment in the master teachers' plans to interpret and adapt the policy expectations on knowledge sharing in their plans, to identify the areas where they plan to make changes and to attribute developmental learning activities and outcomes to them. The knowledge sharing elements of the policy expectations dominate in teachers' planning (sharing experiences, making it public), but teachers' understanding of the opportunities for joint knowledge creation and active forms of involvement in the wider knowledge management context is scattered.

\section{Bibliography}

Allinder, R. M. (1994). The relationship between efficacy and the instructional practices of special education teachers and consultants. Teacher Education and Special Education, 17(2), 86-95.

Bell, M., Cordingley, P., Isham, C., \& Davis, R. (2010). Report of professional practitioner use of research review: Practitioner engagement in and/or with research. Coventry: CUREE, GTCE, LSIS \& NTRP. http://www.curee-paccts.com/node/2303

Bray-Clark, N. \& Bates, R. (2003). Self-efficacy beliefs and teacher effectiveness: Implications for professional development. Professional Educator, 26(1), 13-22.

Campbell, A., McNamara, O., \& Gilroy, P. (2004). Practitioner Research and Professional Development in Education. UK: SAGE publication.

Child, J. (2015). Organization. Contemporary principles and practice: Second edition. UK: John Wiley and Sons Ltd. doi: 10.1002/9781119176862

Cohen, W. M. \& Levinthal, D. A. (1990). Absorptive capacity: A new perspective on learning and innovation. Administrative Science Quarterly, 35, 128-152. doi: 10.2307/2393553

Cole, P. (2012). Linking effective professional learning with effective teaching practice. Melbourne: Australian Institute for Teaching and School Leadership.

Coles, M. \& Werquin, P. (2009). The influence of qualifications frameworks on the infrastructure of VET. In Maclean, R. \& Wilson, D. (szerk.), International handbook -of education for the changing wolrd of work: Bridging academic and vocational learning. Hollandia: Springer. 439-452.

Cordingley, P., Bell, M., Thomason, S., \& Firth, A. (2005). The impact of collaborative continuing professional development (CPD) on classroom teaching and learning. Review: How do collaborative and sustained CPD and sustained but not collaborative CPD affect teaching and learning? http://eppi.ioe.ac.uk/cms/Default.aspx?tabid=136

Darling-Hammond, L., Cook, C., Jaquith, A., \& Hamilton, M. (2012). Creating a comprehensive system evaluating and supporting effective teaching. Stanford, Kalifornia: Stanford Center for Opportunity Policy in Education, Stanford University.

Eden, D. \& Kinnar, J. (1991). Modeling Galatea: Boosting self-efficacy to increase volunteering. Journal of Applied Psychology, 76(6), 770-780. 
Eisenhardt, K. M. \& Martin, J. A. (2000). Dynamic capabilities: What are they? Strategic Management Journal, 21, 1105-1121.

Evetts, J. (2008). Introduction: Professional work in Europe: Concepts, theories and methodologies. European Societies, 10(4), 525-544.

Evetts, J. (2011). A new professionalism? Challenges and opportunities. Current Sociology, 59(4), 406422. doi: $10.1177 / 0011392111402585$

Fazekas Ágnes \& Halász Gábor (2015). A kurrikulum fejlesztését célzó közoktatási programok implementálása. Neveléstudomány, 2014(4), 23-41.

Fazekas Ágnes \& Halász Gábor (2018). Az uniós finanszírozású kurrikulumfejlesztési programok implementálása. Manual. http://www.impala.elte.hu/wp-content/uploads/2013/12/4.Szint\%C3\%A9zis-tanulm\%C3\%A1ny.pdf

Fazekas Ágnes, Halász Gábor, \& Horváth László (2017). Innováció az oktatásban: az Innova kutatás elméleti-fogalmi keretei. Neveléstudomány, 4, 26-43.

Fazekas Ágnes, Halász Gábor, \& Horváth László (2018). Innovációk és innovációs folyamatok a magyar oktatási rendszerben. Educatio, 27(2), 247-264.

Fraser, A. J. (2005). Teacher-led innovation and development to improve professional practice. Sydney: The Winston Churchill Memorial Trust of Australia. https://www.churchilltrust.com.au/media /fellows/Fraser_Andrew_2005.pdf

George, A. A., Hall, G. E., \& Stiegelbauer, S. M. (2013). Measuring implementation in schools: The stages of concern questionnaire. Austin, Texas: SEDL. http://www.sedl.org/cbam/socq manual 201410.pdf

Gist, M. E., Bavetta, A. G., \& Stevens, C. K. (1990). Transfer training method: Its influence on skill generalization, skill repetition, and performance level. Personnel Psychology, 43, 501-523.

Goe, L., Bell, C., \& Little, O. (2008). Approaches to evaluating teacher effectiveness: A research synthesis. Washington: National Comprehensive Center for Teacher Quality.

Gordon Győri János (2009). Tanórakutatás. Budapest: Gondolat Kiadó, Oktatásmódszertani Kiskönyvtár.

Gorman, E. H. \& Sandefur, R. L. (2011). "Golden age," Quiescence, and Revival: How the sociology of professions became the study of knowledge-based work. Work and Occupations, 38(3), 275-302. doi: $\underline{10.1177 / 0730888411417565}$

Guerriero, S. \& Deligiannidi, K. (2017). The teaching profession and its knowledge base. In Guerriero, S. (szerk.), Pedagogical knowledge and the changing nature of the teaching profession. Educational Research and Innovation. Párizs: OECD Publishing. 19-36. http://www.iep.edu.gr/images/ IEP/EPISTIMONIKI_YPIRESIA/Epist_Grafeia/EU_Policy/2017/2017-05-11_OECD-Pedagogical-

Knowledge.pdf

Halász Gábor, Balázs Éva, Fischer Márta, \& Kovács István Vilmos (2011). Javaslat a nemzeti oktatási innovációs rendszer fejlesztésének stratégiájára. Budapest, Oktatáskutató és Fejlesztő Intézet.

Hall, J. N. (2013). Pragmatism, evidence, and mixed methods evaluation. New Directions for Evaluation, 2013(138), 15-26. doi: 10.1002/ev.20054

Hargreaves, D. (2010). Creating a self-improving school system. Nottingham: National College for School Leadership. https://dera.ioe.ac.uk/2093/1/download\%3Fid\%3D133672\%26filename\%3D creating-a-self-improving-school-system.pdf

Hargreaves, A. \& Fullan, M. (2012). Professional capital. New York: Teachers College Press.

Hargreaves, A. \& Goodson, I. (2006). Educational change over time? The sustainability and nonsustainability of three decades of secondary school change and continuity. Educational Quarterly, 42(1), 3-41. 
Ingvarson, L. (2002). Development of a national standards framework for the teaching profession. Camberwell, Ausztrália: Australian Council for Educational Research Publishing.

Ingvarson, L. \& E. Kleinhenz (2003). A review of standards of practice for beginning teachers. Camberwell, Ausztrália: Australian Council for Educational Research.

Ingvarson, L. \& Rowe, K. (2007). Conceptualising and evaluating teacher quality: Substantive and methodological issues. http://research.acer.edu.au/learning_processes/8

Istance, D. \& Kobayashi, M. (2012). Az innováció hálózatai. Az iskolarendszer és az iskolamenedzsment új modelljei. Budapest: Oktatáskutató és Fejlesztő Intézet.

Jackson, D. \& Temperley. J. (2007). The role of practice-to-practice learning in system reform. Paper presented at the American Educational Research Association (AERA) Annual Meeting, Chicago, 9-13 April, 2007.

Kálmán Orsolya (2016). Innovatív pedagógusok az innovatív gyakorlatukról. In Vámos Ágnes (szerk.), Tanuló pedagógusok és az iskola szakmai tőkéje. Budapest: ELTE Eötvös Kiadó. 143-166.

Kennedy, A. (2005). Models of continuing professional development: A framework for analysis. Journal of In-service Education, 31(2), 235-250. doi: 10.1080/13674580500200277

Korthagen, F. (2017). Inconvenient truths about teacher learning: towards professional development 3.0. Teachers and Teaching, 23(4), 387-405. doi: 10.1080/13540602.2016.1211523

McKenzie, P., Santiago, P., Sliwka, P., \& Hiroyuki, H. (2005). Teachers matter: Attracting, developing and retaining effective teachers. OECD, Brüsszel.

McLaughlin, M. W. (1990). The rand change agent study revisited: Macro perspectives and micro realities. Educational Researcher, 19(11), 11-16.

OECD (2003). Recent education policy developments in OECD contries. Educatoin Policy Analysis. Párizs: OECD.

OECD (2014). TALIS 2013 results: An international perspective on teaching and learning. Párizs: OECD.

OECD (2016). Teaching excellence through professional learning and policy reform - Lessons from around the world. Párizs: OECD Published.

Oktatási Hivatal (2016). Útmutató a mesterpedagógus fokozatot megcélzó minösitési eljáráshoz. https://www.oktatas.hu/pub_bin/dload/kiadvanyok/mesterpedagogus_utmutato.pdf

Pedder, D., Opfer, V. D., Mccormick, R., \& Storey, A. (2010). Schools and continuing professional development in England - State of the nation' research study: policy, context, aims and design. Curriculum Journal, 21(4), 365-394.

Sachs, J. (2007). Learning to improve or improving learning: The dilemma of teacher continuing professional development. In Proceedings of the 20st Annual World ICSEI Congress. Ljubljana: National School for Leadership in Education. 3-6.

Sachs, J. (2016). Teacher professionalism: Why are we still talking about it? Teachers and Teaching, 22(4), 413-425.

Sági Matild (2015). A pedagógushivatás megerösitésének néhány aspektusa. Budapest: OFI.

Senge, P. (1990). The fifth discipline: The art and practice of the learning organization. USA: Currency.

TALIS (2009). Összefoglaló jelentés az OECD nemzetközi tanárkutatás (TALIS) elsö eredményeiröl. Budapest: Oktatáskutató és Fejlesztő Intézet. http://www.okm.gov.hu/letolt/kozokt/talis_090618.pdf

Teece, D. J., Pisano, G., \& Shuen, A. (1997). Dynamic capabilities and strategic management. Strategic Management Journal, 18(17), 509-533. https://onlinelibrary.wiley.com/doi/abs/10.1002/\%28 SICI\%291097-0266\%28199708\%2918\%3A7\%3C509\%3A\%3AAID-SMJ882\%3E3.0.CO\%3B2-Z 
Torres, A. C. \& Weiner, J. M. (2018). The new professionalism? Charter teachers' experiences and qualities of the teaching profession. Education Policy Analysis Archives, 26(19). doi: $\underline{10.14507 / \text { epaa.26.3049 }}$

Vera, D., Crossan, M., \& Apaydin, M. (2011). A framework for integrating organizational learning, knowledge, capabilities, and absorptive capacity. In Easterby-Smith, M. \& Lyles, A. (szerk.), Handbook of organizational learning and knowledge management. Chichester: John Wiley and Sons Ltd. 153182.

Vermunt, J. D. \& Endedijk, M. D. (2011). Patterns in teacher learning in different phases of the professional career. Learning and Individual Differences, 21, 294-302.

Vries, de S., Jansen, E. P. W. A., \& van de Grift, W. J. C. M. (2013). Profiling teachers' continuing professional development and the relation with their beliefs about learning and teaching. Teaching and Teacher Education, 33, 78-89.

Villegas-Reimers, E. (2003). Teacher professional development: an international review of the literature. Párizs: International Institute for Educational Planning.

\section{Authors}

Judit Szivák (correspondent), Eötvös Loránd University, Faculty of Education and Psychology, Email: szivak.judit@ppk.elte.hu

Nóra Rapos, Eötvös Loránd University, Faculty of Education and Psychology, E-mail: rapos.nora@ppk.elte.hu

Sándor Lénárd, Eötvös Loránd University, Faculty of Education and Psychology, E-mail: lenard.sandor@ppk.elte.hu

Erika Kopp, Eötvös Loránd University, Faculty of Education and Psychology, E-mail:

kopp.erika@ppk.elte.hu 